\title{
Pengaruh Penerapan Metode Problem Based-Learning Terhadap Hasil Penilaian Mata Kuliah Mobile Programming pada Pendidikan Informatika Jenjang Pendidikan Diploma 3
}

\author{
Dita Lupita Sari, Choirun Niswatin \\ Politeknik Kota Malang \\ Kompleks Pendidikan Internasional Tlogowaru No 3, telp/fax (0341) 754088 \\ e-mail: ditalupitasari@gmail.com
}

\begin{abstract}
Abstrak - Dengan adanya fenomena peningkatan jumlah pengguna aplikasi mobile maka sudah dapat dipastikan kebutuhan akan pengembang aplikasi juga akan meningkat. Dengan prinsip menyediakan lulusan yang sesuai dengan kebutuhan industri,sudah selayaknya institusi pendidikan tinggi memberikan banyak perhatian dalam menghasilkan lulusan yang mumpuni di bidang pengembangan aplikasi mobile. Oleh karena itu dikembangkan metode problem based learning yang diharapkan mampu merangsang daya saing dan kreatifitas mahasiswa dalam proses belajar mengajar mata kuliah pemrograman mobile.

Dalam pengujian hipotesis dihasilkan kesimpulan bahwa nilai kedua kelompok memiliki perbedaan signifikan. Terdapat perbedaan hasil penilaian dari kelompok yang menggunakan metode problem based learning dan kelompok yang tidak menggunakan problem based learning. Kelompok eksperimen memiliki nilai rata-rata lebih tinggi dari kelompok kontrol Dapat disimpulkan bahwa metode problem based learning meningkatkan hasil penilaian pada mata kuliah mobile programming
\end{abstract}

Kata kunci: problem based learning, mobile programming, pendidikan tinggi

\section{Pendahuluan}

Dewasa ini penggunaan perangkat mobile smartphone telah menjadi kebutuhan bagi masyarakat. Hal ini terbukti dengan banyaknya pengguna smartphone di dunia. Sebuah laporan baru dari Emarketer menyatakan bahwa akan terdapat dua miliar pengguna smartphone aktif di seluruh dunia pada tahun 2016. Dan Indonesia merupakan salah satu negara yang mempunyai pertumbuhan terbesar, di bawah China dan India. Tiga negara ini secara kolektif akan menambah lebih dari 400 juta pengguna smartphone baru dari 2014 hingga 2018.

Peningkatan pengguna mobile smartphone akan berdampak pula pada peningkatan akses terhadap aplikasi mobile. Laporan terbaru dari Juniper Research menunjukkan adanya peningkatan cukup besar akan kebutuhan aplikasi di dunia. Aplikasi mobile yang diunduh ke tablet dan smartphone sekitar 235 miliar unduh aplikasi mobile pada tahun ini.

Dengan adanya fenomena peningkatan jumlah pengguna aplikasi mobile maka sudah dapat dipastikan kebutuhan akan pengembang aplikasi juga akan meningkat. Dengan prinsip menyediakan lulusan yang sesuai dengan kebutuhan industri,sudah selayaknya institusi pendidikan tinggi memberikan banyak perhatian dalam menghasilkan lulusan yang mumpuni di bidang pengembangan aplikasi mobile. Oleh karena itu dikembangkan metode problem based learning yang diharapkan mampu merangsang daya saing dan kreatifitas mahasiswa dalam proses belajar mengajar mata kuliah pemrograman mobile.

Problem based learning merupakan suatu inovasi model pembelajaran. Problem based learning merupakan suatu model pembelajaran yang menantang siswa untuk "belajar bagaimana

TELKA, Vol.2, No.2, November 2016, pp. 118 125

ISSN (e): 2540-9123

118

ISSN (p): 2502-1982 
belajar" bekerja secara berkelompok untuk mencari solusi dari permasalahan dunia nyata. Permasalahan ini digunakan untuk mengikat siswa pada rasa ingin tahu pada pembelajaran yang dimaksud. Masalah yang diberikan kepada siswa, sebelum siswa mempelajari konsep atau materi yang berkenaan dengan permasalahan yang harus dipecahkan [6].

Metode ini menuntut mahasiswa untuk lebih aktif mencari informasi. Tidak hanya mengandalkan informasi yang diberikan oleh pengajar karena pengajar hanya berperan sebagai fasilitator. Sumber informasi bisa dari mana saja, misalkan dari internet, perpustakaan baik di kampus maupun di luar kampus atau datang langsung mengunjungi lokasi kasus. Hal ini memungkinkan mahasiswa tidak hanya berada di dalam kelas dalam proses belajar mengajar. Namun, dalam metode problem based learning, pengajar menjadi fasilitator yang harus terus mengarahkan mahasiswa untuk dapat menyelesaikan sesuai dengan yang ditargetkan. Sehingga tetap harus ada komunikasi intensif antara mahasiswa dan pengajar. Dengan demikian perlu adanya pengembangan metode problem based learning yang dikombinasikan dengan pembelajaran online sehingga tujuan yang diharapkan dapat tercapai dengan maksimal[1].

\section{Metode Penelitian}

Pendekatan yang digunakan dalam penelitian ini adalah pendekatan kuantitatif. Data penelitian pada pendekatan kuantitatif berupa angka-angka dan analisis menggunakan statistik[2]. Alasan peneliti menggunakan pendekatan kuantitatif karena peneliti bermaksud untuk menghilangkan subjektifitas dalam penelitian.

Metode penelitian yang digunakan dalam penelitian ini adalah eksperimen kuasi dengan pola nonequivalent control group design. Eksperimen itu sendiri adalah observasi di bawah kondisi buatan (artificial condition) di mana kondisi tersebut dibuat dan diatur oleh si peneliti ${ }^{[3]}$. Metode eksperimen memungkinkan untuk menilai hasil dari ada atau tidaknya pengaruh dari sebuah tindakan yang diberikan pada kelompok. Eksperimen kuasi dengan pola nonequivalent control group design dipilih karena pertimbangan sulitnya pengontrolan terhadap semua variabel yang mempengaruhi variabel yang sedang diteliti. Dalam jenis pola nonequivalent control group design perlakuan ekspresimen memberikan pretest-postest yang tidak ekuivalen pada kelompok eksperimen dan kelompok kontrol. Dimana kelompok eksperimen dan kelompok kontrol tidak dipilih secara random[7].

Desain ini terdiri dari dua kelompok, yakni kelompok eksperimen dan kelompok kontrol. Kelompok eksperimen dan kelompok kontrol diberikan pre test terlebih dahulu. Kemudian kelompok eksperimen diberi perlakuan tertentu yang tidak dilakukan terhadap kelompok kontrol.Baik kelompok kontrol maupun kelompok eksperimen kemudian diberikan post test untuk melihat efek dari perlakuan pada kelompok ekperimen. Sehingga dapat diketahui apakah terdapat perubahan yang terjadi pada kelompok eksperimen dan dapat membandingkannya dengan kelompok kontrol. Adapun gambaran eksperimen kuasi dengan pola nonequivalent control group design dijelaskan pada Tabel 1[2].

Tabel 1. Desain Eksperimen Kuasi Pola Nonequivalent Control Group Design

\begin{tabular}{|c|c|c|c|}
\hline Kelas & Pre Test & Variabel Bebas & Post Test \\
\hline Eksperimen & $\mathrm{O}_{1}$ & $\mathrm{X}$ & $\mathrm{O}_{2}$ \\
\hline Kontrol & $\mathrm{O}_{3}$ & - & $\mathrm{O}_{4}$ \\
\hline
\end{tabular}

Keterangan :

O1 : Pengukuran kemampuan awal kelompok eksperimen

$\mathrm{O} 2$ : Pengukuran kemampuan akhir kelompok eksperimen

$\mathrm{X}$ : Pemberian perlakuan

O3 : Pengukuran kemampuan awal kelompok kontrol

O4 : Pengukuran kemampuan akhir kelompok control 
Sampel adalah bagian dari jumlah dan karakteristik yang dimiliki oleh populasi. Sampel yang digunakan harus benar-benar representatif ${ }^{[5]}$. Karena itu dipilihlah sampel penelitian mahasiswa jurusan Teknik Informatika semester 4 di Politeknik Kota Malang dan Vokasi Universitas Brawijaya. Karena mahasiswa tersebut sedang sama-sama menempuh mata kuliah mobile programming. Mahasiswa jurusan Informatika Politeknik Kota Malang berperan sebagai kelas eksperimen yang diberi perlakuan dengan menerapkan metode pembelajaran problem based learning. Mahasiswa jurusan Informatika Vokasi Universitas Brawijaya berperan sebagai kelas kontrol yang diterapkan metode pembelajaran ceramah dan penugasan.

Perhitungan yang dilakukan dalam penelitian ini menggunakan perangkat lunak SPSS versi 23. Data yang diperoleh dari hasil pre test dan post test kemudian dilakukan uji prasyarat analisis terlebih dahulu yaitu dengan melakukan uji normalitas dan uji homogenitas ${ }^{[8]}$. Uji normalitas dilakukan untuk mensyaratkan bahwa data yang akan dianalisis berdistribusi normal. Data yang terdistribusi normal dianggap dapat mewakili populasi ${ }^{[9]}$. Uji normalitas yang dilakukan dalam penelitian ini dengan menggunakan uji normalitas Saphiro-Wilk. Jika nilai Sig $>0.05$ maka data berdistribusi normal dan jika nilai Sig $<0.05$ maka data tidak berdistribusi normal.

$$
\begin{gathered}
\mathrm{T}_{3}=\frac{1}{\mathrm{D}}+\sum_{\mathrm{i}=1}^{\mathrm{k}} \mathrm{a}_{\mathrm{i}}\left(\mathrm{x}_{\mathrm{n}-\mathrm{i}+1}-\mathrm{x}_{1}\right)^{2} \\
\mathrm{D}=\sum_{\mathrm{i}=1}^{\mathrm{n}}\left(\mathrm{x}_{\mathrm{i}}+\overline{\mathrm{x}}\right)^{2} \\
\mathrm{G}=\mathrm{b}_{\mathrm{n}}+\mathrm{c}_{\mathrm{n}}+\ln \left(\frac{\mathrm{T}_{3}-\mathrm{d}_{\mathrm{n}}}{1-\mathrm{T}_{3}}\right)
\end{gathered}
$$

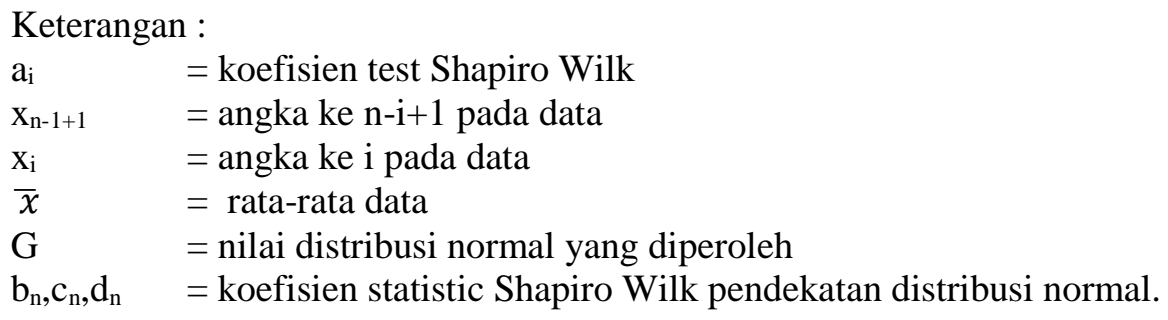

Uji homogenitas dilakukan sebagai uji prasyarat analisis untuk mengetahui apakah kedua kelompok berasal dari jenis populasi yang sama atau tidak. Jika nilai Sig $>0.05$ maka data homogen dan jika nilai Sig $<0.05$ maka data tidak homogen.

$$
\mathrm{F}=\quad \frac{\text { varian terbesar }}{\text { varian terkecil }}
$$

Setelah dilakukan uji prasyarat analisis kemudian dilanjutkan dengan uji kemampuan awal. Uji kemampuan awal digunakan untuk menguji perbedaan rata-rata nilai pre test dari kedua kelompok. Uji kemampuan awal menggunakan independent sample T-test. Jika nilai Sig $>0.05$ maka tidak ada perbedaan signifikan dan jika nilai Sig $<0.05$ maka ada perbedaan signifikan. 


$$
\begin{gathered}
t=\frac{x a-x b}{\operatorname{Sp} \sqrt{\left(\frac{1}{n a}\right)+\left(\frac{1}{n b}\right)}} \\
\mathrm{Sp}^{2}=\frac{(n a-1) S a^{2}-(n b-1) S b^{2}}{n a-n b-2}
\end{gathered}
$$

Keterangan :

$\mathrm{xa}=$ rata-rata kelompok a

$\mathrm{xb}=$ rata-rata kelompok $\mathrm{b}$

$\mathrm{Sp}=$ Standar deviasi gabungan

$\mathrm{Sa}=$ Standar deviasi kelompok a

$\mathrm{Sb}=$ Standar deviasi kelompok $\mathrm{b}$

na = banyaknya sampel di kelompok a

$\mathrm{nb}=$ banyaknya sampel di kelompok b

Tahap selanjutnya adalah melakukan uji hipotesis. Uji hipotesis dilakukan dengan memberikan post test kepada kedua kelompok untuk melihat apakah terdapat perbedaan hasil belajar bagi kelompok eksperimen yang diterapkan metode belajar problem based learning dengan kelompok kontrol yang tidak dikenai tindakan metode belajar problem based learning. Hipotesis alternatif (Ha) dan hipotesis nihil (Ho) yang diajukan pada penelitian ini adalah sebagai berikut:

Ha: Terdapat pengaruh positif signifikan penerapan problem based learning terhadap hasil penilaian mata kuliah mobile programming.

Ho: Tidak terdapat pengaruh positif signifikan penerapan problem based learning terhadap hasil penilaian mata kuliah mobile programming.

Uji hipotesis menggunakan metode Mann Whitney test. Jika nilai Sig > 0.05 maka Ho diterima Ha ditolak. Jika nilai Sig < 0.05 maka Ho ditolak Ha diterima.

Keterangan :

$$
\mathrm{Z}=\frac{\mathrm{U}-\frac{\mathrm{n} 1 . \mathrm{n} 2}{2}}{\sqrt{\frac{\mathrm{n} 1 \cdot \mathrm{n} 2 \cdot(\mathrm{n} 1+\mathrm{n} 2+1)}{12}}}
$$

$\mathrm{U}=$ Statistik uji

$\mathrm{n} 1$ = banyaknya anggota sampel 1

$\mathrm{n} 2$ = banyaknya anggota sampel 2 


\section{Hasil dan Analisis}

\subsection{Uji Normalitas}

Tabel 2. Hasil Uji Normalitas Pre Test

\begin{tabular}{|ll|r|r|r|r|r|r|}
\hline \multirow{2}{*}{} & \multirow{2}{*}{ Kelompok } & \multicolumn{3}{|c|}{ Kolmogorov-Smirnov $^{\mathrm{a}}$} & \multicolumn{3}{c|}{ Shapiro-Wilk } \\
\cline { 2 - 8 } & Statistic & \multicolumn{1}{c|}{$\mathrm{df}$} & \multicolumn{1}{c|}{ Sig. } & \multicolumn{1}{c|}{ Statistic } & \multicolumn{1}{c|}{$\mathrm{df}$} & \multicolumn{1}{c|}{ Sig. } \\
\hline Nilai & InformatikaPoltekom & .113 & 19 & $.200^{*}$ & .934 & 19 & .208 \\
& InformatikaVokasiuB & .109 & 23 & $.200^{*}$ & .952 & 23 & .329 \\
\hline
\end{tabular}

*. This is a lower bound of the true significance.

a. Lilliefors Significance Correction

Pada kelompok Informatika Poltekom nilai Sig=0.208, nilai Sig > 0.05. Pada kelompok Informatika Vokasi UB nilai Sig=0.329, nilai Sig $>0.05$. Maka dapat disimpulkan bahwa data pre test untuk kedua kelompok terdistribusi normal.

Tabel 3. Hasil Uji Normalitas Post Test

\begin{tabular}{|ll|r|r|r|r|r|r|}
\hline \multirow{2}{*}{} & \multirow{2}{*}{ Kelompok } & \multicolumn{3}{|c|}{ Kolmogorov-Smirnov $^{\text {a }}$} & \multicolumn{3}{c|}{ Shapiro-Wilk } \\
\cline { 2 - 8 } & Statistic & \multicolumn{1}{c|}{$\mathrm{df}$} & \multicolumn{1}{c|}{ Sig. } & \multicolumn{1}{c|}{ Statistic } & \multicolumn{1}{c|}{ df } & \multicolumn{1}{c|}{ Sig. } \\
\hline \multirow{2}{*}{ Nilai } & InformatikaPoltekom & .253 & 19 & .002 & .874 & 19 & .017 \\
& InformatikaVokasiUB & .225 & 24 & .003 & .883 & 24 & .010 \\
\hline
\end{tabular}

a. Lilliefors Significance Correction

Pada kelompok Informatika Poltekom nilai Sig=0.017, nilai $\operatorname{Sig}<0.05$. Pada kelompok Informatika Vokasi UB nilai Sig=0.010, nilai $\operatorname{Sig}<0.05$. Maka dapat disimpulkan bahwa data post test untuk kedua kelompok tidak terdistribusi normal.

\subsection{Uji Homogenitas}

Tabel 4. Hasil Uji Homogenitas Pre Test

Nilai

\begin{tabular}{|l|r|r|r|}
\hline $\begin{array}{l}\text { Levene } \\
\text { Statistic }\end{array}$ & df1 & df2 & Sig. \\
\hline .203 & 1 & 41 & .654 \\
\hline
\end{tabular}


Tabel 5. Hasil Uji Homogenitas Post Test Nilai

\begin{tabular}{|c|c|c|c|}
\hline $\begin{array}{l}\text { Levene } \\
\text { Statistic }\end{array}$ & df1 & df2 & Sig. \\
\hline .260 & 1 & 41 & .613 \\
\hline
\end{tabular}

Pada hasil uji homogenitas pre test nilai $\mathrm{Sig}=0.654$, nilai Sig $>0.05$. Sehingga data dinyatakan homogen. Sedangkan pada hasil uji homogenitas post test nilai Sig $=0.613$, nilai Sig $>0.05$. Sehingga data dinyatakan homogen. Maka dapat disimpulkan bahwa data pre test dan data post test pada kedua kelompok dinyatakan homogen yang berarti kedua kelompok berasal dari jenis populasi yang sama.

\subsection{Uji Kemampuan Awal}

Setelah data dinyatakan lolos uji prasyarat analisis maka selanjutnya dilakukan uji kemampuan awal.

Tabel 6. Hasil Uji Kemampuan Awal Menggunakan Metode Independent Simple T-Test

\begin{tabular}{|c|c|c|c|c|c|c|c|c|c|c|}
\hline & \multicolumn{2}{|c|}{$\begin{array}{c}\text { Levene's Test for Equality of } \\
\text { Variances }\end{array}$} & \multicolumn{7}{|c|}{ t-test for Equality of Means } \\
\hline & & \multirow[b]{2}{*}{$\mathrm{F}$} & \multirow[b]{2}{*}{ Sig. } & \multirow[b]{2}{*}{$t$} & \multirow[b]{2}{*}{ df } & \multirow[b]{2}{*}{ Sig. (2-tailed) } & \multirow{2}{*}{$\begin{array}{l}\text { Mean } \\
\text { Difference }\end{array}$} & \multirow{2}{*}{$\begin{array}{l}\text { Std. Error } \\
\text { Difference }\end{array}$} & \multicolumn{2}{|c|}{$\begin{array}{l}95 \% \text { Confidence Interval of the } \\
\text { Difference }\end{array}$} \\
\hline & & & & & & & & & Lower & Upper \\
\hline & $\begin{array}{l}\text { Equal variances } \\
\text { assumed }\end{array}$ & .145 & .705 & -.066 & 40 & .947 & -02093 & .31542 & .65841 & 61656 \\
\hline & $\begin{array}{l}\text { Equal variances not } \\
\text { assumed }\end{array}$ & & & -.065 & 36.055 & .948 & -02093 & .31966 & . .66920 & 62735 \\
\hline
\end{tabular}

Tabel 7. Hasil Rata-Rata Nilai Pre Test

\begin{tabular}{|ll|r|r|r|r|}
\hline & Kelompok & $N$ & Mean & Std. Deviation & \multicolumn{1}{c|}{$\begin{array}{c}\text { Std. Error } \\
\text { Mean }\end{array}$} \\
\hline Nilai & InformatikaPoltekom & 23 & 7.0957 & .95178 & .19846 \\
& InformatikaVokasiUB & 19 & 7.1166 & 1.09232 & .25060 \\
\hline
\end{tabular}

Pada hasil uji kemampuan awal nilai $\mathrm{Sig}=0.947$, nilai $\mathrm{Sig}>0.05$. Nilai rata-rata nilai pre test pada kelompok Informatika Poltekom adalah 7.0957 dan nilai rata-rata nilai pre test pada kelompok Informatika Vokasi UB adalah 7.1166. Maka dapat disimpulkan bahwa nilai pre test pada kedua kelompok tidak memiliki perbedaan signifikan.

\subsection{Uji Hipotesis}

Setelah dilakukan pengujian awal dengan melakukan pre test kepada kedua kelompok maka selanjutnya dilakukan uji hipotesis. Uji hipotesis dilakukan dengan menggunakan metode Mann Whitney test dikarenakan data post test tidak terdistribusi normal. 
Tabel 8. Hasil Uji Kemampuan Awal Menggunakan Metode Mann Whitney Test

\begin{tabular}{|l|r|}
\hline & \multicolumn{1}{|c|}{ Nilai } \\
\hline Mann-Whitney U & 113.000 \\
Wilcoxon W & 389.000 \\
Z & -2.666 \\
Asymp. Sig. (2-tailed) & .008 \\
\hline
\end{tabular}

Tabel 9. Hasil Rata-Rata Nilai Post Test

\begin{tabular}{|ll|r|r|r|}
\hline & Kelompok & N & Mean Rank & \multicolumn{1}{c|}{$\begin{array}{c}\text { Sum of } \\
\text { Ranks }\end{array}$} \\
\hline Nilai & InformatikaVokasiUB & 23 & 16.91 & 389.00 \\
& InformatikaPoltekom & 19 & 27.05 & 514.00 \\
& Total & 42 & & \\
\hline
\end{tabular}

Pada hasil uji hipotesis nilai $\mathrm{Sig}=0.008$, nilai $\mathrm{Sig}<0.05$. Nilai rata-rata nilai post test pada kelompok Informatika Poltekom adalah 16.91 dan nilai rata-rata nilai post test pada kelompok Informatika Vokasi UB adalah 27.05. Maka dapat disimpulkan bahwa nilai post test pada kedua kelompok memiliki perbedaan signifikan sehingga Ho ditolak dan Ha diterima. Terdapat pengaruh positif signifikan penerapan problem based learning terhadap hasil penilaian mata kuliah mobile programming.

\section{Kesimpulan}

Dalam pengujian normalisasi pre test (belum diberi tindakan problem based learning), data berdistribusi normal sedangkan dalam pengujian normalisasi post test (setelah diberi tindakan problem based learning) data tidak berdistribusi normal. Hal ini dikarenakan terlalu banyak nilainilai ekstrim dalam satu set data yang akan menghasilkan distribusi skewness(miring). Karena itu dilakukan pengujian hipotesis pada post test dengan menggunakan metode Mann Whitney test.

Dalam pengujian homogenitas pre test dan post test dihasilkan kesimpulan bahwa kedua jenis data homogen. Dan hal ini membuktikan bahwa kedua kelompok berasal dari jenis populasi yang sama. Berdasarkan pengujian pra syarat analisis yaitu dengan uji normalisasi dan uji homogenitas pada data pre test dan post test maka dinyatakan bahwa data normal dan homogeny sehingga proses penelitian dapat dilanjutkan ke tahap selanjutnya.

Dalam pengujian kemampuan awal dalam pre test (belum diberi tindakan problem based learning) dihasilkan kesimpulan bahwa hasil rata-rata pre test tidak memiliki perbedaan signifikan. Hal ini menunjukkan bahwa kemampuan awal kedua kelompok sebelum diberi tindakan metode problem based learning hampir sama.

Dalam pengujian hipotesis dalam post test (setelah diberi tindakan problem based learning) dihasilkan kesimpulan bahwa nilai kedua kelompok memiliki perbedaan signifikan sehingga Ha diterima dan Ho ditolak. Dapat disimpulkan bahwa terdapat perbedaan hasil penilaian dari kelompok yang menggunakan metode problem based learning dan kelompok yang tidak menggunakan problem based learning. Kelompok eksperimen memiliki nilai rata-rata lebih tinggi dari kelompok kontrol Dapat disimpulkan bahwa metode problem based learning meningkatkan hasil penilaian pada mata kuliah mobile programming.

Berdasarkan hasil penelitian ini dapat dijadikan masukan bagi perguruan tinggi untuk menggunakan metode problem based learning dalam proses belajar mengajar. 


\section{Daftar Pustaka}

[1] Fajar Wahyu Setiabudi.(2014). Model Problem-Based Learning Berbasis Mobile Techology Untuk Mata Kuliah Sistem Informasi Geografis Di Politeknik Kota Malang. Jakarta:Seamolec.

[2] Sugiono. (2007). Metode Penelitian Pendidikan. Bandung: Alfabeta..

[3] Moh Nazir. (2005). Metode Penelitian. Jakarta: Ghalia Indonesia.

[4] Duwi Priyatno. (2013). Mandiri Belajar Analisis Data dengan SPSS. Yogyakarta: Mediakom

[5] Sugiyono. (2010). Metode Penelitian Kuantitatif Kualitatif dan R\&D. Bandung: Alfabeta.

[6] Daryanto. (2014). Pendekatan Pembelajaran Saintifik Kurikulum 2013. Yogyakarta: Gava Media.

[7] James .A .(1973). Quasi-Experimental Approaches to Social Science dalam QuasiExperimental Approaches (ed. James A. Caporaso \& Leslie L. Roos Jr). Northwestern University PressCook

[8] Januardi. (2013). Efektifitas Model Pembelajaran Problem Solving Terhadap Hasil Belajar Siswa Kelas X Mata Pelajaran Ekonomi SMA Hidayatul Muhsinin Kubu raya. Pontianak: Universitas Tanjungpura.

[9] Evi Tri Wulandari.(2015). Pengaruh Penerapan Problem Based Learning Terhadap Kemandirian Belajar Siswa Kelas IV SD Se-Gugus III Kecamatan Temon Kabupaten Kulon Progo. Yogyakarta: Universitas Negeri Yogyakarta. 